\title{
Study of angiopoietin and plasminogen genes in hereditary angioedema
}

\author{
(DDTatielly Kruk ${ }^{*}$ \\ (D) Herberto José Chong-Neto' \\ (iD) Marina Mendonça Dias ${ }^{3}$ \\ (iD) Wagner Narciso Campos ${ }^{3}$ \\ (iD) Adriana Santos Moreno ${ }^{3}$ \\ (iD) Liya Regina Mikami² \\ (iD Lilian Pereira Ferrari² \\ (DLuísa Karla de Paula Arruda \\ Nelson Rosário Filho ${ }^{1}$
}

\begin{abstract}
1. Programa de Pós-Graduação em Medicina Interna e Ciências da Saúde. Complexo Hospital de Clínicas, Universidade Federal do Paraná - UFPR, Curitiba, PR, Brasil.

2. Faculdade de Ciências da Saúde, Setor de Genética e Biologia Molecular, Centro Universitário Autônomo do Brasil - UNIBRASIL, Curitiba, PR, Brasil; 3. Laboratório de Alergia e Imunologia Clínica da Universidade de São Paulo - (Faculdade de Medicina de Ribeirão Preto) - USP, Ribeirão Preto, SP, Brasil. * Biomedicine - Master's Degree student in Internal Medicine and Health Sciences UFPR.
\end{abstract}

\section{SUMMARY}

OBJECTIVE: To investigate the presence of the Angiopoietin 1 (ANGPT1) and Plasminogen (PLG) mutations in patients with Hereditary Angioedema (HAE) and normal C1 esterase inhibitor (C1-INH) levels, who do not harbor the F12 gene mutation.

METHODS: Patients clinically diagnosed with HAE but without C1-INH deficiency or dysfunction and F12 gene mutation were evaluated. DNA extraction, quantification, and dilution were performed at a concentration of $100 \mathrm{ng} / \mu \mathrm{L}$, followed by a DNA amplification (PCR) for molecular evaluation of exon 2 of the ANGPT1 gene and exon 9 of the PLG gene for identification of mutations c.807G>T / p.A119S and c.988A>G / p.K330E, respectively. The PCR product was evaluated in 1\% agarose gel electrophoresis. Sequencing was performed using the Sanger method. The electropherograms were analyzed using the FASTA ${ }^{\circledR}$ program.

RESULTS: DNA samples from 15 women were sequenced. Their ages ranged from 10 to 60 years and the normal $C 1$ esterase and C4 inhibitor serum levels ranged from 22 to $39 \mathrm{mg} / \mathrm{dL}$ and from 10 to $40 \mathrm{mg} / \mathrm{dL}$, respectively. No mutations were detected in the analyzed exons of ANGPT1 and PLG. However, a single-nucleotide polymorphism (SNP) was detected in two homozygotic and five heterozygotic patients.

CONCLUSION: Further studies are needed to evaluate these SNPS and scrutinize their potential for use as molecular markers of HAE and as novel therapeutic targets.

KEYWORDS: Bradykinin, Mutation, Angiopoietin-1, Plasminogen.

\section{INTRODUCTION}

Hereditary Angioedema (HAE) is a rare and severe genetic disease of the kallikrein-kinin system caused by a deficiency of the C1-esterase inhibitor (C1-INH), which is inherited in an autosomal dominant manner. It affects approximately 1 in 60,000 inhabitants (ranging from 1:10,000 to 1:160,000) belonging to different 
ethnic groups. Although it is an autosomal dominant disease, it is detected more frequently and severely in women. ${ }^{1-5}$

Family history with similar clinical manifestations reinforces the HAE diagnosis. About $75-80 \%$ of HAE cases occur in the same family while $20-25 \%$ of cases are due to novel spontaneous mutations..$^{1-3}$

HAE can be classified into three phenotypes: (1) quantitative C1-INH deficiency due to mutations, located throughout the SERPING1 gene, that affect the structure of the protein and impair its secretion; (2) C1-INH dysfunction due to a mutation in exon 8 of the SERPING1 gene that results in the secretion of a non-functional protein; and (3) normal C1-INH that may be associated with mutations in the F12, ANGPT1, $P L G$, and Kininogen 1 (KNG1) genes, mainly found in female patients with normal C1-INH protein levels and activity. ${ }^{1-14}$

A variant of the ANGPT1 gene was reported to interfere with the interaction between the angiopoietin protein and its natural receptor, endothelial tunica of the kinase cell- (TIE2), in endothelial cells leading to increased vascular permeability and edema. ${ }^{12,15,16}$

A mutation in the $P L G$ gene has also been reported to increase fibrinolysis, which in turn causes plasmin formation and increased levels of bradykinin, leading to edema (PLG). ${ }^{11,13,14}$

The presence of genetic alterations in different genes emphasizes the importance of molecular genetic analysis in Brazilian patients to expand our knowledge on HAE and identify new strategies for the treatment of this disease..$^{11,12}$

The objective of this study was to investigate the presence of mutations in the ANGPT1 and PLG genes of HAE patients without C1-INH deficiency or dysfunction and F12 gene mutations.

\section{METHODS}

A $5 \mathrm{~mL}$ blood sample was collected from each patient via venous puncture, followed by genomic DNA extraction using the Wizard Genomic DNA Purification ${ }^{\circledR}$ kit (Promega). DNA was quantified in a spectrophotometer and, when necessary, diluted to a concentration of $100 \mathrm{ng} / \mu \mathrm{L}$ for sequencing. After extraction, the DNA was used to amplify exon 2 of the ANGPT1 gene and exon 9 of the PLG gene by polymerase chain reaction (PCR). The PCR products were resolved by $1 \%$ agarose gel electrophoresis and subjected to Sanger sequencing for detecting the mutations c.807 G>T / p.A119S and c.988 A>G / p.K330E in exon 2 of the ANGPT1 gene and exon 9 of the $P L G$ gene, respectively.

The forward primer of the ANGPT1 gene was 5'GTTGACAACTGGATTCCTGTG3', and that of the PLG was 5'CTTAGTTTAGTACTGGAACGCAGG3', and reverse primer of the ANGPT1 gene was 5'CGCATAGCATGTCAGGCAGTC3', and that of the PLG was 5'CAGGCTTTCTGACCACAATAGC3'. The sequencing reaction was performed using the Big Dye Terminator $^{\circledR}$ v.3.1 kit (Thermo Fischer Scientific, Waltham, MA, USA).

Samples of purified sequencing reaction products were heated at $80^{\circ} \mathrm{C}$ for 15 minutes to inactivate the ExoSAP enzyme and subsequently, the products were precipitated.

After the precipitation of the DNA in the plates, it was resuspended in a specific buffer and DNA sequencing was performed by the Sanger method.

The electropherograms were analyzed by FASTA ${ }^{\circledR}$, a software package for the alignment of DNA and protein sequences. ${ }^{17}$

\section{STATISTICS}

The data were inserted in an Excel ${ }^{\circledR}$ spreadsheet. The allele frequencies were combined on alleles I and II. Then the frequencies of the mutations in both alleles were added and compared with the relative frequencies reported in the specific literature using the Chi-square test with a result of $p<0.05$ was not considered as significant.

\section{RESULTS}

A total of 69 patients with HAE, including both genders, were treated at the Allergy and Immunology Clinic of the Hospital de Clínicas Complex, Federal University of Paraná - Curitiba (CHC-UFPR). Of these, 27 patients diagnosed with normal C1-INH HAE were evaluated; as all of them were women, this study focused on female patients.

Patients with C1-INH deficiency or dysfunction, patients with mutations involving the SERPING1 gene and other forms of non-hereditary angioedema were also excluded.

The clinical features were recorded using a questionnaire form. The 27 patients were evaluated for F12 gene mutations and 12 of them were excluded 
TABLE 1. CHARACTERISTICS OF PATIENTS STUDIED

\begin{tabular}{|c|c|c|c|c|c|c|c|}
\hline FAMILY & PATIENT & RELATIONSHIP & GENDER & BIRTHDATE & $\begin{array}{l}\text { AGE SYMPTONS } \\
\text { STARTED }\end{array}$ & $\begin{array}{l}\text { FAMILY HIS- } \\
\text { TORY }\end{array}$ & TREATMENT \\
\hline 1 & $\begin{array}{l}\text { HAEO01 } \\
\text { HAEO03 }\end{array}$ & $\begin{array}{l}\text { SISTER (HAEO03) } \\
\text { SISTER (HAEOO01) }\end{array}$ & $\begin{array}{l}F \\
F\end{array}$ & $\begin{array}{l}06 / 19 / 1979 \\
12 / 27 / 1961\end{array}$ & $\begin{array}{l}36 \text { YEARS OLD } \\
52 \text { YEARS OLD }\end{array}$ & $\begin{array}{l}\text { YES } \\
\text { YES } \\
\end{array}$ & $\begin{array}{l}\text { NO } \\
\text { NO }\end{array}$ \\
\hline 2 & HAE005 & $X X X X X$ & $\mathrm{~F}$ & 11/16/1981 & 18 YEARS OLD & YES & NO \\
\hline 3 & HAE006 & $X X X X X$ & $\mathrm{~F}$ & 07/13/2009 & 6 YEARS OLD & YES & $\mathrm{NO}$ \\
\hline 4 & HAEOO7 & $X X X X X$ & $\mathrm{~F}$ & 02/12/1979 & 15 YEARS OLD & YES & NO \\
\hline 5 & HAE008 & $X X X X X$ & $\mathrm{~F}$ & 02/02/1987 & 17 YEARS OLD & YES & $\mathrm{NO}$ \\
\hline 6 & HAE009 & $X X X X X$ & $\mathrm{~F}$ & 06/22/1986 & 25 YEARS OLD & YES & $\mathrm{NO}$ \\
\hline 7 & HAE011 & $X X X X X$ & $\mathrm{~F}$ & 11/12/1982 & 20 YEARS OLD & YES & $\mathrm{NO}$ \\
\hline 8 & HAE012 & $X X X X X$ & $\mathrm{~F}$ & 03/24/1980 & 16 YEARS OLD & YES & $\mathrm{NO}$ \\
\hline 9 & HAE013 & $X X X X X$ & $\mathrm{~F}$ & 01/10/1981 & 04 YEARS OLD & YES & NO \\
\hline 10 & HAE014 & $X X X X X$ & $\mathrm{~F}$ & 06/22/1969 & 30 YEARS OLD & YES & NO \\
\hline 11 & $\begin{array}{l}\text { HAE015 } \\
\text { HAE016 }\end{array}$ & $\begin{array}{l}\text { SISTER (HAE016) } \\
\text { SISTER (HAE015) }\end{array}$ & $\begin{array}{l}F \\
F\end{array}$ & $\begin{array}{l}\text { 08/12/1983 } \\
\text { 05/03/1988 }\end{array}$ & $\begin{array}{l}15 \text { YEARS OLD } \\
\text { 05 YEARS OLD }\end{array}$ & $\begin{array}{l}\text { YES } \\
\text { YES }\end{array}$ & $\begin{array}{l}\text { NO } \\
\text { NO }\end{array}$ \\
\hline 12 & HAE019 & $X X X X X$ & $\mathrm{~F}$ & 11/13/1975 & 39 YEARS OLD & YES & NO \\
\hline 13 & HAEO21 & $X X X X X$ & $\mathrm{~F}$ & 10/08/1985 & 22 YEARS OLD & YES & NO \\
\hline
\end{tabular}

from the study because they presented positive results. Therefore, 15 patients without $F 12$ gene mutations were examined for the presence of mutations in exon 9 of the ANGPT1 gene and exon 2 of the PLG gene.

Biochemical tests revealed normal C1-INH and C4 serum levels ranging from 22 to $39 \mathrm{mg} / \mathrm{dL}$ and 10 to $40 \mathrm{mg} / \mathrm{dL}$, respectively in the patients with HAE, who were aged between 10 and 60 years, and had 1 to 4 flares lasting for 3 days on an average per month. All patients reported a family history of angioedema (TABLE 1).

The patients reported flare symptoms in during emotional stress and menstrual cycle, leading to emotional problems and depression in some cases as well as financial burden. Chart 1 shows the most common signs and symptoms of HAE.

DNA sequence analysis did not detect the mutation c.807G $>$ T / p.Ala119Ser in the ANGPT1 gene and the mutation c. $988 \mathrm{~A}>\mathrm{G} /$ p. lys330Glu in the PLG gene.

\section{GRAPH 1. MOST FREQUENT SIGNS AND SYMPTOMS}

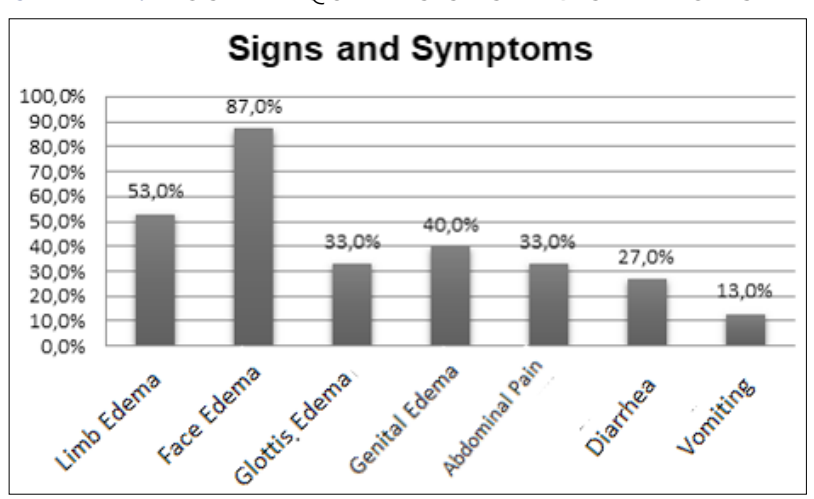

However, a single-nucleotide polymorphism (SNP) in the $P L G$ gene was identified.

The electropherograms were evaluated by FASTA ${ }^{17}$ and are shown below:

NORMAL SEQUENCE:

CAATCCTGACGGAAAAGGGCCATGGTG

MUTATED SEQUENCE:

GCAATCCTGACGGARAAAGCCATGGTG

HOMOZYGOUS SEQUENCE:

CCACGGAACAGTTGGCTCCCAC

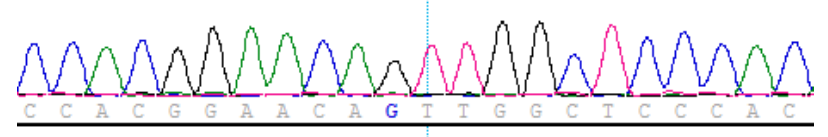

HETEROZYGOUS SEQUENCE

CCACGGAACAA/GTTGGCTCCCAC

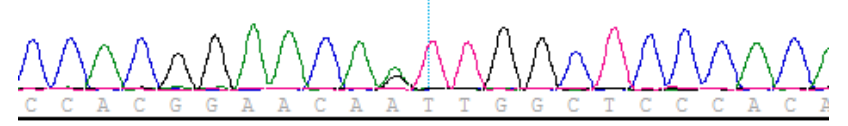

SNP silent c.1083A $>$ G p.Gln 361 $($ CAA CAG $\rightarrow)$

\section{DISCUSSION}

Bork and Binkley have described a type of HAE with normal $\mathrm{C} 1$ inhibitor, in which the functional activity of C1-INH and C4 levels remained normal, suggesting that HAE diagnosis would be more accurate through genetic analysis. ${ }^{18,19}$

HAE with normal C1-INH levels is the rarest among 
the HAE phenotypes described in literature, occurring in about $30 \%$ of patients. ${ }^{11}$ F12 gene mutation was present in $44 \%$ of the 27 patients included in this study, although this prevalence is higher than that cited in other studies and may be related to ethnic differences among the populations studied.

Initially, the symptoms of HAEs with normal C1-INH were shown to affect predominantly women and to be associated with estrogen usage; however, because it is an autosomal dominant disease, men are also affected but are often asymptomatic. ${ }^{9}$ The 15 patients who participated in this study reported clinical features that corroborate the literature such as limb, face and genital edema, abdominal pain, diarrhea, and vomiting. Of these, $87 \%$ reported face edema as the most common symptom of HAE with normal C1-INH. ${ }^{1,3,9,11}$

Of the two mutations that were evaluated in the 15 patients, the c.807G $>$ T/ p.Ala119Ser in exon 2 of the ANGPT1 gene has been described in an Italian family; ${ }^{12}$ however, in this study, this mutation has been detected in a Brazilian family of non-Italian origin. ${ }^{16}$ The c.988 A>G / p. lys330Glu mutation in exon 9 of the $P L G$ gene has been described in 13 families in Europe, ${ }^{11}$ including 3 in France and 2 families in Japan. ${ }^{14,15}$ Considering the colonization and the population brazilian composition of $47.5 \%$ of European descendants according to IBGE ${ }^{23}$, this research in Brazilian patients is justified.

The mutations described were not identified in the patients. However, a silent homozygous SNP c. $1083 \mathrm{~A}>\mathrm{G} /$ p. Gln 361 $=(\mathrm{CAA} \mathrm{CAG} \rightarrow)$ in the $P L G$ gene was detected in two unrelated patients, where the presence of base $\mathrm{G}$ occurred on both alleles. Furthermore, five patients were heterozygous for this SNP . This SNP is identified as silent since it does not alter the protein sequence and has no clear effect on the gene function or the phenotype of the individual carrying the mutation. ${ }^{20-22}$

According to the literature, ${ }^{24}$ the incidence of the SNP rs13231 flanking the PLG gene mutation c. $1083 \mathrm{~A}>\mathrm{G}$ p.Gln $361=\mathrm{CAA} \mathrm{CAG} \rightarrow$ is $0.78 \%$ and 0.21 (or 21\%) for alleles A and G, respectively. According to the $\mathrm{ABRAOM}^{25}$ database, the incidence of this SNP in the Brazilian population was reported for the A allele $0.74 \%$ and for the $\mathrm{G}$ allele $0.26 \%$. In the sample studied, the frequency of the SNP was 30\% (9/30), higher than that described for Brazilian and European populations; however, this is not a statistically significant difference $(p>0.05)$.

All patients who participated in the study were clinically evaluated and diagnosed with Hereditary Angioedema of unknown cause (HAE-U), according to the criteria established by the Brazilian Guidelines for the diagnosis and treatment of hereditary angioedema. ${ }^{1}$

These Brazilian Guidelines were published in 2017 and therefore, cite only the F12 gene mutations. After that, three more mutations have been identified as related to HAE with normal C1-inhibitor, including the two mutations analyzed in this study., ${ }^{9,10}$

This study has some limitations, particularly the small sample size. Nevertheless, the incidence of HAE in the Brazilian population is $1 / 160,000$ and of these, only $30 \%$ have HAE with normal C1-INH. ${ }^{1-3}$

\section{CONCLUSION}

No mutations were detected in the evaluated exons in the 15 patients studied; however, 7 patients had a silent SNP, c.1083A $>$ G / p.Gln 361 $=($ CAA CAG $\rightarrow$ ).

Further studies on SNPs are needed to clarify whether they can be used as molecular markers of HAE and as therapeutic targets for new treatments.

\section{RESUMO}

OBJETIVO: Investigar a presença das mutações no gene Angiopoietina (ANGPT1) e gene Plasminogênio (PLG) em pacientes com Angioedema Hereditário (AEH) com inibidor C1 esterase (C1-INH) normal e negativos para mutação do gene F12.

MÉTODOS: Foram avaliados pacientes com diagnóstico clínico de AEH sem deficiência ou disfunção de C1-INH e negativos para mutação do gene F12. Realizou-se extração, quantificação e diluição do DNA a uma concentração de $100 \mathrm{ng} / \mathrm{uL}$, em seguida amplificação do DNA (PCR) para avaliação molecular do exon 2 do gene ANGPT1 e do exon 9 do gene PLG para identificação das mutações c.807G $>$ T.p.A179S e c.988A>G p.K330E, respectivamente. O produto da PCR foi avaliado em eletroforese em gel de agarose $1 \%$. Foi realizado o sequenciamento pelo método de Sanger. As análises dos eletroferogramas foram realizadas pelo programa FASTA ${ }^{\circledR}$. 
RESULTADOS: Foram sequenciadas amostras de 15 mulheres, idade entre 10 e 60 anos, com níveis séricos de inibidor de $C 1$ esterase e C4 normais variando de 22 a 39mg/dL e 10 a 40mg/dL, respectivamente. Não foram identificadas mutações nos éxons analisados dos genes ANGPT1 e PLG. Entretanto no gene PLG foram encontrados polimorfismo de nucleotídeo único (SNP), em duas pacientes homozigotas e cinco heterozigotas.

CONCLUSÃo: Mais estudos sobre SNP são necessários para esclarecer estes achados pois eles podem ser utilizados como marcadores moleculares do AEH e alvo para novos tratamentos.

PALAVRA CHAVE: Bradicinina, Mutação, Angiopoietina-1, Plasminogênio.

\section{REFERENCES}

1. Giavina-Bianchi P, Arruda LK, Aun MV, Campos RA, Chong-Neto HJ, Constantino-Silva RN, et al. Diretrizes brasileiras para o diagnóstico e tratamento do angioedema hereditário - 2017. Arq Asma Alerg Imunol. 2017;1(1):23-48.

2. Sim DW, Park KH, Lee JH, Park JW. A case of type 2 hereditary angiodema with SERPING1 mutation. Allergy Asthma Immunol Res. 2017;9(1):96-8.

3. Valle SOR, França AT, Campos RA, Grumach AS. Angioedema hereditário. Rev Bras Alerg Imunopatol. 2010;33(3):80-7.

4. Chagas KN, Arruk VG, Andrade MEB, Vasconcelos DM, Kirschfink M, Duarte AJS, et al. Angioedema hereditário: considerações sobre terapia. Rev Assoc Med Bras. 2004;50(3):314-9.

5. Bernstein |A. Severity of hereditary angioedema, prevalence, and diagnostic considerations. Am J Manag Care. 2018;24(14 Suppl):S292-8.

6. Rijavec M, Korošec P, Šilar M, Zidam M, Miljković ], Košnik M. Hereditary angioedema nationwide study in Slovenia reveals four novel mutations in SERPING1 gene. PLoS One. 2013;8(2):56712.

7. Freiberger T, Grombiriková H, Ravcuková B, Jarkovský |, Kuklinek P, Krystufková $\mathrm{O}$, et al. No evidence for linkage between the hereditary angiooedema clinical phenotype and the BDKR1, BDKR2, ACE or MBL2 gene. Scand I Immunol. 2011;74(1):100-6.

8. Arruda LKP, Ferraro MF. Angioedema hereditário: busca por melhor diagnóstico. Rev Bras Alerg Imunopatol. 2010;33(6):213-14.

9. Dias MM, Moreno AS, Maia LSM, Nunes FL, Campos WN, Ferriani MPL et al. A cost-effective algorithm for diagnosis of hereditary angioedema with normal C1 inhibitor: applying molecular approach to clinical practice. | Allergy Clin Immunol Pract. 2020;8(1):419-21.

10. Bork K, Wulff K, Rossmann H, Steinmüller-Magin L, Braenne I, Witzke $\mathrm{G}$, et al. Hereditary angioedema cosegregating with a novel kininogen 1 gene mutation changing the $\mathrm{N}$-terminal cleavage site of bradykinin. Allergy. 2019;74(12):2479-81.

11. Bork K, Wulff K, Meinke P, Wagner N, Hardt J, Witzke G. A novel mutation in the coagulation factor 12 gene in subjects with hereditary angioedema and normal C1-inhibitor. Clin Immunol. 2011;141(1):31-5.

12. Bafunnoo V, Firiniu D, D'Apolito M, Cordisco G, Loffredo S, Leccese A, et al. Mutation of the angiopoietin-1 gene (ANGPT1) associates with a new type of hereditary angioedema. | Allergy Clin Immunol. 2018;141(3):1009-17.
13. Bork K, Wulff K, Steinmüller-Magin L, Braenne I, Staubach-Renz P, Witzke $G$, et al. Hereditary angioedema with a mutation in the plasminogen gene. Allergy. 2017;73(2):442-50.

14. Yakushiji H, Hashimura C, Fukuoka K, Kaji A, Miyahara H, Kaname S, et al. A missense mutation of the plasminogen gene in hereditary angioedema with normal C1 inhibitor in Japan. Allergy. 2018;73(11):2244-7.

15. Belbézier A, Hardy G, Marlu R, Defendi F, Dumestre Perard C, Boccon-Gibod I, et al. Plasminogen gene mutation with normal $\mathrm{C} 1$ inhibitor hereditary angioedema: three additional French families. Allergy. 2018;73(11):2237-9.

16. Zurow BL. Hereditary angioedema with normal $\mathrm{C} 1$ inhibitor: four types and counting. J Allergy Clin Immunol. 2018;141(3):884-5.

17. Lipman DJ, Pearson WR. Rapid and sensitive protein similarity searches. Science. 1985;227(4693):1435-41.

18. Bork K, Barnstedt SE, Koch P, Traupe H. Hereditary angioedema with normal C1-inhibitor activity in women. Lancet. 2000;356(9225):213-7.

19. Binkley KE, Davis A 3rd. Clinical, biochemical, and genetic characterization of a novel estrogen-dependent inherited form of angioedema. J Allergy Clin Immunol. 2000;106(3):546-50.

20. Instituto Brasileiro de Geografia e Estatística - IBGE. Tabela população residente por raça, cor ou religião 2010. [cited 2019 Jul 7]. Available from: https://sidra.ibge.gov.br/Tabela/2094

21. Komar AA. SNPs, silent but not invisible. Science. 2007;315(5811):466-7.

22. Pennisi E. A closer look at SNPs suggests difficulties. Science. 1998;281(5384):1787-9.

23. Kimchi-Sarfaty C, Oh JM, Kim IW, Sauna ZE, Calcagno AM, Ambudkar SV, et al. A "silent" polymorphism in the MDR1 gene changes substrate specificity. Science. 2007;315(5811):525-8.

24. National Center for Biotechnology Information, U.S. National Library of Medicine. dbSNP short genetic variations. [cited 2019 Jul 7]. Available from: https://www.ncbi.n/m.nih.gov/snp/rs13231\#frequency_tab

25. Arquivo Brasileiro Online de Mutações - ABRAOM. Brazilian genomic variants. [cited 2019 Jul 7]. Available from: http://abraom.ib.usp.br/search. php 